\title{
New dangers in East Germany for science
}

\section{- Change brings materialism, competition - Initial consensus breaking down \\ BerIIn}

THE opening of the Berlin Wall has brought new danger to East German research institutes. Democratic reforms in research institutes are being held up by dissension; meanwhile, pressure created by the opening of the borders is growing every day.

A microcosm of the debate about the way to reorganize research in East Germany can be seen at the Central Institute for Molecular Biology, ZIMB in German, at Berlin-Buch. Political change has come rapidly to ZIMB. But, surprisingly, exhilaration and joy are not so evident. The subdued reaction might be explained by the peculiar psychology of life in a closed country. "We have lived all our lives within sight of the wall", says Thomas Hanke, a young ZIMB researcher, "It would have driven us crazy to think all the time, 'You cannot jump over it.' So we learned not to think about it."

Hanke, who was born in West Berlin, is one of many who reject the materialism of Western culture. For a lot of East Germans, he says, "real freedom means being able to buy ten Coca-Colas, drink them in public and fire the cans into the corner!" Such views often go along with a desire for reunification and the quick solution this could mean for East German economic problems. But acrimonious debate over whether reunification is the best course has already begun to splinter the popular coalition that rallied behind New Forum to drive the government from power.

The "greatest fear" now is that the coalition might break down and chaos follow, says Werner Ebeling, a professor of physics at the Humboldt University. He and other academics are struggling to find a 'third way' for East Germany that does not involve annexation, confederation, or some other form of reunification with West Germany.

Tom Rapoport, a senior molecular biologist at ZIMB, sees a particular danger for science in the opening of the wall. "It means that we are now competing with the West for good students, postdoctoral fellows and funds. Now we have to be able to offer people something to keep them here, and we have to work on bringing people in from outside."

Rapoport estimates that there are only about 15 groups in the whole of East Germany that come up to international standards in molecular biology and biochemistry, and only a few of these have publications to prove it. Rapoport has been prodding granting agencies in West Germany and the United States for research support. So far, the response has been "negative or neutral", but he plans to keep "bombarding them" with queries

If help does not come soon, Rapoport says, "basic research here will die" because East Germany will not or cannot finance it. "We can't wait", he says. Together with colleagues at ZIMB, Rapoport is discussing the establishment of a peer-reviewed granting system in East Germany, assuming that hard currency comes from somewhere. Rapoport recognizes that such a competitive system would shut out at least half the research groups in the country. "Our industry can use them", he says. "It has no good research of its own."

Jens Reich, a molecular biologist at ZIMB who is also a prominent member of New Forum, does not agree. He likens Rapoport's plan to "raw capitalism" with none of the social supports that East Germany must continue to provide if it is to be different from the West. Adopting Rapaport's plan, like adopting the Western economic system, would be a "gesture of capitulation", he says.

Reich would prefer to give junior and senior scientists as well as technical personnel a say in the choice of group leaders and institute directors. He sees a research institute as a parliament, where the leader can continue only when he has the support of a majority of the members. The decision to pursue certain research goals may be taken by a committee, but it must be approved by the institute as a whole

Rapoport would accept a scientific advisory board with veto power over a director's decisions. But he rejects "letting a cleaning woman decide" how money is spent.

Rapoport admits that he is in deep conflict over the social effects of an achievement-oriented science policy. "We'll dig the grave of a "third way' by insisting on efficiency", he says. "Personally, I want the social net that Reich advocates. But professionally, I cannot accept it. It is a conflict between feeling and reason."

The debate at ZIMB and elsewhere will have to move forward quickly. Only a few short months remain before the elections planned for May 1990, and reformers still face two daunting tasks - not only must they offer reasonable alternatives to the old system but they must also dismantle
Dingell reopens GalloPasteur row

\section{Washington}

Allegations in the Chicago Tribune that National Cancer Institute (NCI) scientist Robert Gallo did not tell the full story of the discovery of the AIDS virus in his celebrated disagreement with Luc Montagnier of the Pasteur Institute are to be evaluated by the NCI.

This much is disclosed in a letter from William Raub, acting director of National Institutes of Health (NIH), to John Dingell, chairman of the House of Representatives subcommitee on Oversights and Investigations. At some point, the letter says, Raub and the NIH Office of Scientific Integrity will review the NCI's findings.

The letter is a reply to an earlier letter from Dingell asking whether allegations raised in the Chicago Tribune article have been investigated and which continues: "If they have not been investigated, does NIH plan to conduct an investigation . . . ? If so, what office and persons at NIH will be involved in performing the inquiry, and what procedure will be used? When will the inquiry start and what is the estimated time for completion?"

The Chicago Tribune article, of the 19 November, was written by Pulitzer-prizewinning journalist John Crewdson (see Nature 342,$462 ; 1989$ ). Among other things the article repeated allegations raised during the Pasteur dispute (eventually settled out of court) that Gallo's identification of the AIDS virus, reported in 1984, rested on the availability of isolates provided by Montagnier.

Dingell's letter to NIH is stern, almost accusatory, in tone, claiming that previous investigations by his staff show that "NIH has turned a blind eye to misconduct by senior scientists . . .". It demands that the new allegations should be "thoroughly investigated ....".

Raub's reply seems unlikely to satisfy Dingell. It does not say what form the evaluation will take nor whether it has been given the high priority that Dingell would clearly like to see. Nothing is said of when the evaluation will be complete, nor does Raub say whether the NCI evaluation is a response to Dingell's demand for an inquiry or an initiative by NCI. But Raub does say that the Chicago Tribune article appears to be erroneous and incomplete in some respects.

Alun Anderson

the old structures of power, which are effectively still in place except at the highest levels. As Reich puts it, "the head has been chopped off but the corpse is still lying in the swamp". It is no coincidence that demonstrations and meetings go on outside working hours. "The courage we saw on the streets has not reached the workplace", he says. Steven Dlckman 